\title{
Working With Clients Who Self-Injure: Providing Alternatives
}

\author{
Kelly L. Wester and Heather C. Trepal
}

\begin{abstract}
The topic of self-injurious behavior (SIB) has been gaining widespread attention. Although college counselors engage in various types of treatments in order to uncover the underlying reasons for a client's SIB, there is another step in treatment that might be helpful to clients who self-injure. This step involves alternatives to self-injury. The authors provide various alternatives to self-injury and discuss matching the alternative to the function and type of SIB.
\end{abstract}

$\mathrm{T}$ The topic of self-injurious behavior (SIB) has been gaining widespread attention in the mainstream culture (Favazza, 1998) and professional literature (Zila \& Kiselica, 2001). SIBs have been defined as "all behaviors involving the deliberate infliction of direct physical harm to one's own body without the intent to die as a consequence of the behavior" (Simeon \& Favazza, 2001, p. 1). Thus, SIB encompasses a wide range of behaviors, from skin picking, hair pulling, and cutting and burning to bone breaking and selfsurgery (Favazza, 1987; Simeon \& Favazza, 2001). Although the most severe cases of SIB can result in unexpected and unintentional death, SIB is not a suicide attempt. When an individual self-injures, there is no intent to die (Alderman, 1997; Crowe \& Bunclark, 2000; Favazza \& Conterio, 1989; Herpertz, 1995). Alderman explained this difference by stating that an act of self-injury is typically done in order to sustain life and to cope with pain or emotions, whereas suicide is an attempt to end life.

Research conducted on SIB has primarily focused on the prevalence rates; however, the majority of these studies have been conducted with psychiatric populations (prevalence typically around $40 \%$ ) and the general population ( $1.4 \%$ to $6.5 \%$; Kravitz, Rosenthal, Teplitz, Murphy, \& Lesser, 1960; R. R. Ross \& McKay, 1979; Simeon \& Favazza, 2001). Very few studies have focused on prevalence rates in college populations. One study (Gratz, 2001) that did focus on SIB in a college population found that $35 \%$ reported a history of deliberate self-harm, with $15 \%$ reporting more than 10 incidents of self-injury in the past and $9 \%$ reporting more than 100 incidents of self-injury. Researchers are unsure of the reason for the higher rates of SIBs at the university level than in the general population. It is unclear if the higher rates are actual increases in the number of individuals selfharming at the college age, clients becoming more comfortable with disclosing, or clinicians more skilled at identifying SIBs. Regardless of the reason, the known rates of SIBs are increasing.

Kelly L. Wester, Department of Counseling and Educational Development, University of North Carolino ot Greensboro; Heather C. Trepal, Department of Counseling, Educational Psychology, and Adult and Higher Education, University of Texas ot San Antonio. The authors thank Karen Eileen Hall, who assisted in compiling a list of various alternotives to self-injury. Correspondence concerning this article should be addressed to Kelly L. Wester, 219 Curry Building, Department of Counseling and Educational Development, University of North Carolina ot Greensboro, PO Box 26170, Greensboro, NC 27402 (e-mail: klwester@uncg.edu). 
Although SIBs have been found to be increasing and are becoming more prevalent in the general and college populations, treatment methods have received mixed reviews. Various types of treatments and methods have been suggested for working with clients who self-injure (e.g., Graff \& Mallin, 1967; Pipher, 1994; R. R. Ross \& McKay, 1979; Yaryura-Tobias, Neziroglu, \& Kaplan, 1995); however, no one treatment has been found to be the most effective. Zila and Kiselica (2001) reported that limited information on SIBs in the literature frequently hinders proper treatment and can ultimately lead to a counselor's frustration, repulsion, or fear of the behavior. However, regardless of the treatment method, SIB can increase in frequency and severity when a client begins to work on underlying causes of the behavior (Foxx, $1982,2003)$. Thus, it might be helpful for a client to have an alternative to SIB while working through some of the core, emotionally difficult, concerns. Very little literature covers alternatives to SIB; however, alternatives for selfinjury can be provided as a substitute to a client who is increasing the use of SIB due to working on difficult, emotional issues in counseling and who is unable or unwilling to minimize or distinguish his or her SIB. Alternatives can be a substitute for SIB because they can provide similar sensations or visual stimuli as the original SIB, without tissue damage. Providing alternative behaviors to clients should not be used as a treatment method or cure for SIB. The purpose of this article is to provide a brief overview of SIB, along with providing example alternative behaviors to SIB that might be helpful for college counselors working with clients who self-injure. These alternatives are a step in counseling that might help minimize or decrease the severity of the behavior while the client continues to uncover the underlying reasons for the behavior. Limitations to alternatives are also presented.

\section{Reasons for Self-Injury}

With SIBs increasing and the serious consequences that can result (e.g., scarring, rejection from peers and/or family, and death), some researchers have attempted to identify risk factors or reasons why individuals engage in this behavior. Some researchers have suggested that SIBs are related to various childhood traumas (e.g., childhood physical or sexual maltreatment; Crowe, 1997; Levenkron, 1998; Simeon \& Favazza, 2001; Tantam \& Whittaker, 1992). Although researchers have found the co-occurrence of childhood trauma and SIBs to be fairly high (up to $80 \%$; Tantam \& Whittaker, 1992), this does not necessarily mean that the abuse is the main, or only, cause of self-harm (Crowe \& Bunclark, 2000); not all abused children choose to self-injure.

Alderman (1997) suggested that individuals who engage in SIBs may be unable to regulate or control their emotions and may find it difficult to identify, express, or release the emotions they have. Some researchers have even suggested that SIB is a way of coping with emotions, because self-injuring individuals may not have learned to modulate, identify, or express their feelings, nor have they found other ways of coping (Alderman, 1997; Favazza \& Simeon, 
1995; Haines \& Williams, 1997; Pattison \& Kahan, 1983). Other researchers and clinicians believe individuals self-injure due to being out of touch with reality, being in a dissociated state, feeling shame, dealing with stressful events, or keeping memories from reoccurring (Alderman, 1997; Favazza, 1987, 1998; Favazza \& Simeon, 1995; Himber, 1994; Levenkron, 1998; S. Ross \& Heath, 2002; Strong, 1998). Overall, it appears that self-injury assists individuals in keeping or gaining control over their lives, whether it is in the form of controlling emotions or pain, feeling "real," or expressing oneself.

Although a few researchers have suggested various forms of treatment for clients who self-injure, a full discussion of these interventions is beyond the scope of the current article. It can be difficult to work with clients who selfinjure for multiple reasons. One of the main reasons, and predicaments, is that SIB can become worse before it ever improves (Foxx, 1982, 2003). SIB typically serves as a coping mechanism that is activated by an increase in emotional arousal (Favazza, 1987; van der Kolk, Perry, \& Herman, 1991; Winchel \& Stanley, 1991), and it assists the client in gaining a feeling of control or relieving tension (Gardner \& Gardner, 1975). In counseling, where the goal is to uncover the causes of the current problem or interference with functioning, a client is bound to be emotionally aroused-which for a self-injuring client might result in an increase in frequency or severity of SIB in order to manage the emotional response. Depending on the severity and/or frequency of the existing SIB, allowing the behavior to worsen may not be an option. However, in order for self-injury to decrease or be extinguished, the underlying reasons or causes (e.g., childhood trauma, abuse, inability to regulate emotions) need to be addressed in counseling. Efforts at getting the client to stop self-injury tend to fail because the client can experience a sense of being misunderstood (Himber, 1994). In addition, "behavioral interventions, ... alone, may involve significant dangers for the client" (Turp, 1999, p. 310) because clients have indicated that they resort to potentially more dangerous behaviors if the stimulus and sensation of self-injury are removed.

Although most college counselors would like their clients to abstain from SIB, clients and researchers have reported that this might not be an achievable goal, at least in the beginning (Crowe \& Bunclark, 2000; Strong, 1998). Attempting to completely extinguish SIB typically does not work, and the most that can be achieved is to reduce either the frequency or the severity (Crowe $\&$ Bunclark, 2000). Strong quoted one client who said, "Abstinence-just cutting the behavior off-is not the way for me anymore. . . I have to fill that space with other ways of dealing with my problems so that I won't have to hurt myself anymore" (p. 159). Thus, a college counselor can consider providing to his or her client a viable substitution, or alternatives, to self-injury. While college counselors engage in various types of treatments and therapeutic methods in an attempt to uncover the underlying reason for a client's SIB, providing alternative behaviors prior to and during the treatment might be helpful to some self-injuring clients. 


\section{Finding Alternatives to Self-Injury}

\section{What Are Alternatives?}

In clinical practice, we have used alternatives to SIB that have been drawn from suggestions by individuals who self-injure or by other authors (e.g., Alderman, 1997; GeoCities, n.d.; Mosiac Minds, n.d.; Psyke.org, n.d.) as being effective in minimizing and decreasing SIBs. Providing alternatives to self-injury can be a step in the counseling process that occurs prior to or during treatment and therapeutic interventions that attempt to uncover or resolve underlying causes of the client's SIB. Alternatives to self-injury are safer methods that a client might use to receive a similar type of feeling or sensation without causing tissue damage. Alternative behaviors should be matched to clients' reactions and emotions, what they need at a specific point in time to cope, or to the emotions or feelings they typically have prior to self-injuring. A suggested sequence in providing alternatives involves the following steps: (a) initial assessment (including frequency, duration, severity, medical history, or complications), (b) assessing the reasons or purpose for self-injury, (c) determining the client's stopping point, (d) providing appropriate alternatives to self-injury (i.e., matching the alternative to the purpose or reason and the client's stopping point), and finally (e) continuing treatment to determine the underlying reasons for self-injury.

\section{Assessment of Clients Who Self-Injure}

With the prevalence of SIB increasing in the population, it is appearing in counseling sessions more often. As White Kress (2003) suggested, the first responsibility of a counselor is to assess for self-injuring behavior by a client and then determine the frequency, duration, onset, severity, and impulsivity of the SIB. This will help in the process of determining the alternatives to selfinjury that a counselor might provide to a client. The information that is obtained can assist the counselor in determining if the client's SIB would be considered high risk, thus, possibly resulting in accidental death or serious bodily damage. White, McCormick, and Kelly (2003) discussed ethical considerations when a counselor is determining whether he or she should report the SIB and suggested that a counselor should respect a client's autonomy, even if it does not make sense to the counselor. However, White et al. did mention that when nonmaleficence (the "do no harm" principle) outweighs the client's autonomy (e.g., multiple emergency room visits, serious infections), the counselor should report the behavior. Beyond the initial assessment, there are two crucial pieces of information that a college counselor needs to gather prior to providing an alternative to the current method of self-injury: (a) the reason or purpose of the behavior and (b) the client's stopping point.

\section{Reason or Purpose of the Behavior}

As stated earlier, researchers have suggested that there can be many reasons that client's self-injure, including to manage emotions, deal with anxiety, or cope with 
stressful events (Favazza, 1987; Favazza \& Simeon, 1995; S. Ross \& Heath, 2002). After an initial assessment of the SIB, and once severity has been assessed, it is important that college counselors determine the function of the SIB. Due to the wide variety of reasons why an individual begins and continues to self-injure, counselors should not presuppose why a client engages in this behavior. It is important for the college counselor to understand the behavior from the client's perspective by asking questions such as, What do the behaviors mean to the client? What reason does the client believe he or she engages in the behavior? (White Kress, 2003). The answers to these questions will provide a direction for the college counselor in determining the type of alternative to offer to his or her client who self-injures.

For example, a client may burn himself when he feels an overwhelming sense of anger: a way to control or take his mind off of his anger or to control himself so he does not lash out and harm others. Another client may choose to cut on herself in order to bring back a memory of childhood when she was being beat with a belt by her father: a way to either reconnect with her father or to punish herself for something she did that she felt was wrong. Thus, clients can engage in SIB for very different reasons. One of the ways a college counselor can use alternatives to SIB is to suggest an alternative that matches the reason a client engages in self-injury.

\section{Stopping Point for Self-Injury}

Along with reasons for self-injury, college counselors should also pay attention to the stopping point of self-injury for a client. The stopping point is the point at which self-injury has served its purpose for the client (e.g., stopped memories from reoccurring, held emotions under control, helped the client to feel alive). Does the client typically realize when the SIB has helped him or her to cope? Does the client stop once he or she begins to feel pain? Once the client sees blood on his or her skin? Once he or she has reached a particular adrenaline high? Although the SIB typically serves some function or purpose for the client, a client can sometimes inform the counselor of when he or she has reached a stopping point at which he or she has cut, burned, or skin-picked enough in order to feel better or to manage psychological pain. The stopping point is another aspect of self-injury that can be used by a counselor to match possible alternatives for clients. For example, a client may stop self-injury based on a visual aspect (e.g., seeing blood or a burn mark) or a sensation of pain or numbness that is a result of the self-injury.

\section{Providing Appropriate Alternatives to Self-Injury}

After completing an initial assessment of the SIB and assessing the client's reason for self-injury and stopping point, college counselors can provide appropriate alternatives to SIBs. If a client can identify the function of the SIB and the 
point at which he or she has "coped" with the current stressor or emotion, a college counselor can introduce alternatives to self-injury. If a client cannot determine his or her stopping point, a college counselor can gain this information throughout his or her assessment of the client's SIB. Each client has unique reasons for, and stopping points of, SIB. Thus, college counselors should match these unique aspects to the alternatives that they offer clients. Table 1 shows different types of categories for the reason someone might self-injure.

\section{Alternatives for Reasons Individuals Self-Injure}

Alternatives for anger and aggression. One reason an individual might self-injure may be due to an overwhelming feeling of anger or aggression. Thus, the individual might cut on himself, bang his head, or slash his skin, stopping selfinjury when he feels that enough anger has been released. If the purpose of SIB for a client is to release anger or aggression, then a college counselor might suggest alternatives that would assist the client in managing these emotions. Some of these alternatives might include ripping up paper; throwing ice cubes, eggs, or other nondamaging but loud, messy items at a wall; or punching pillows or throwing darts at nonanimate objects, all forms of alternatives for anger and aggression (see Table 1 ).

Alternatives for restlessness. Another reason for self-injury is being worrisome or feeling restless, as if one's mind will not stop. The client typically will engage in forms of self-injury in order to stop herself from distressing or tormenting herself with her own thoughts. Alternatives to restlessness can be helpful in delaying or minimizing self-injury with this type of client. These alternatives tend to take up time or cause the individual to put his or her mind temporarily on another task, until the worrying either ends or becomes manageable. Thus, the counselor might suggest physical activity, household cleaning, or taking a crayon and drawing on paper. In counseling, the first author had a male adolescent client finger paint on a large poster taped to a wall when he felt like self-injuring due to worrying and obsessive thoughts. This way he could apply as much pressure as he needed to, use specific colors, and make as detailed or as large of swipes with the paint as he wanted.

Alternatives to emotion regulation. Experiencing intense feelings can be unbearable, thus a client may have the need to regulate emotions or feel in control. According to Favazza (1987), when attempting to regulate emotions, a self-injuring individual will experience an external situation in which he experiences intense feelings that become intolerable. As an example, an individual will self-injure by cutting himself on his arm quickly five times in order to terminate or control these feelings. In this example, instead of cutting his arm, the client might choose the alternative of drawing on his arm or quickly slashing lines on a piece of paper five times. If it is the sensation that he is seeking, and not the act of five lines, he might choose to brush his skin with a toothbrush or hold an ice cube on his skin for a certain period of time, both of which will create a sensation but not damage the skin and tissue as 


\section{TABLE 1}

\section{Alternatives to Self-Injury}

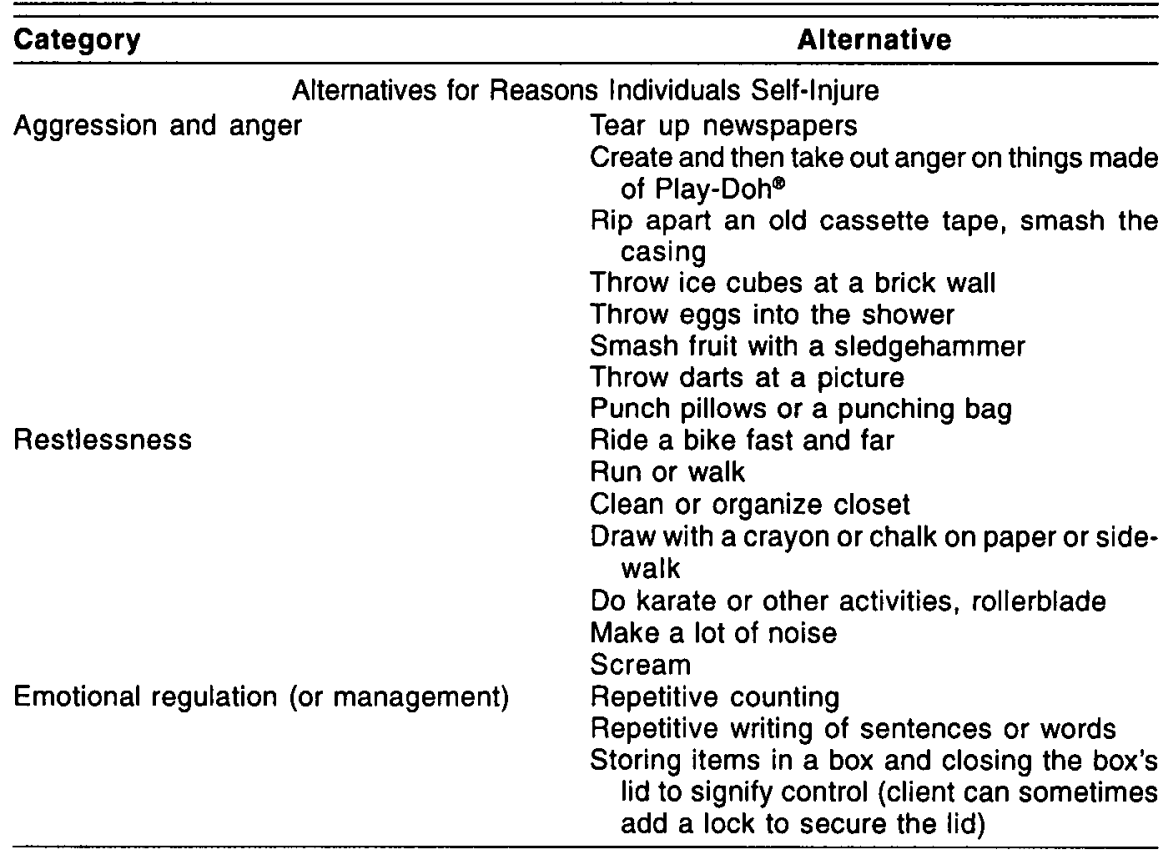

Alternatives for Stopping Point of Individuals Who Self-Injure

Visuals

Sensations

Paint the areas where the client usually hurts himself or herself

Draw red lines on arm with a washable, nontoxic felt marker

Draw slash lines on a piece of paper

Take a cold shower

Hold ice cube on specific area of skin

Rub Ben-Gay ointment on skin

Put a rubber band on wrist or other area of body and snap it

Brush skin with toothbrush

Focusing

Creative

\section{Miscellaneous Alternatives}

Use hands to create something out of PlayDoh $^{\oplus}$ or clay

Breathe deeply or use relaxation techniques Focus on what is real and around oneself

Try to think out loud or silently in another language

Draw or paint what cannot be expressed in words

Write down what one is feeling, without thinking (i.e., free association)

Visualize ripping up one's feelings

Read about self-injury (appropriate books and online materials)

Do collage work (including tearing up or out pictures, picking colors) 
would a razor. The second author of this article had a female client who reported that in order to regulate her emotions and feel more under control, she would count repetitively or write the same sentence over and over again, setting a high number, such as 200 , before she allowed herself to stop writing. This repetitive nature tends to assist a client in calming down, focusing his or her energy on something mundane, and being able to think before acting impulsively.

A client who uses self-injury as a way to gain control might make statements such as "I cut only five times and then I know I am okay" or "I know how far to cut, once I cut far enough to draw blood without having to have stitches, then I feel better." College counselors should keep in mind that cutting is not the only behavior that a client might use to gain self-control. A few examples of other behaviors that could be used include burning, pulling hair, banging one's head, self-tattooing, or skin pricking.

\section{Alternatives for the Stopping Point of Individuals Who Self-Injure}

Alternative visuals or sensations. If something visual or a sensation is the stopping point for a client, a counselor can provide alternative visuals or alternative sensations. Alternatives from the visual category tend to mimic what the client might see when he or she engages in self-injury. Thus, if a client states that he stops cutting himself when he sees blood on his arm, an alternative that the counselor might offer would be to draw red lines on his arm with a marker or to paint the areas in which he wants to hurt himself. However, if the client tends to stop injuring herself when she feels a particular sensation, such as pain, heat, or burning, then the college counselor should offer an alternative to sensations. One sensation alternative is to rub a toothbrush directly on the skin. Although this alternative can produce a burning sensation, it does not permanently damage the skin or tissue.

Miscellaneous alternatives. One of the goals in working with clients who selfinjure is to get them to work on delaying the time between the thought of selfinjuring and the actual behavior. Sometimes this delay might be only a few seconds, while other times it can be an entire day or a week. However, sometimes clients need something to occupy their time, at least in the immediate moments when the self-injuring thoughts can become an obsession. Table 1 provides examples (see focusing alternatives) to help a client delay impulsive behavior. Some of these alternatives include simply using one's hands to do something else (e.g., create something out of Play-Doh ${ }^{\oplus}$ ), to meditate or do deep breathing and relaxation techniques, or to concentrate on one's surrounding or other topics. Sometimes other alternatives, such as creative alternatives, can be used to delay engagement of self-injury or to release emotions that the client does not have the words to express. These forms of miscellaneous alternatives are also helpful when the reason for the SIB, or the stopping point, is unclear to the client and the counselor, because they can be adjusted to fit the needs of the client. 


\section{Conclusion}

In sum, alternatives to self-injury are not designed to treat the roots of the SIB. They are designed to provide a temporary relief from a potentially dangerous behavior so that a college counselor can continue to work with the client at finding the true underlying reason for the SIB. It should also be noted that some clients may not choose to use alternatives, or the alternatives may not work for them. Once again, college counselors need to view each client as unique, because what may work for one client may not work for another; therefore, a college counselor should explore and attempt to understand self-injury from the client's perspective.

\section{References}

Alderman, T. (1997). The scarred soul: Understanding and ending self-inflicted violence. Oakland, CA: New Harbinger.

Crowe, M. (1997). Deliberate self-harm. In D. Bhugra \& A. Monro (Eds.), Troublesome disguises: Underdiagnosing psychiatric symptoms (pp. 206-225). London: Routledge.

Crowe, M., \& Bunclark, J. (2000). Repeated self-injury and its management. International Review of Psychiatry, 12, 48-53.

Favazza, A. R (1987). Bodies under siege: Self-mutilation in culture and psychiatry. Baltimore: Johns Hopkins University Press.

Favazza, A. R. (1998). The coming age of self-mutilation. Journal of Nervous and Mental Diseases, 186, 259-268.

Favazza, A. R., \& Conterio, K. (1989). The plight of chronic self-mutilators. Community Mental Health Journal, 24, 22-30.

Favazza, A. R, \& Simeon, D. (1995). Self-mutilation. In E. Hollander \& D. Stein (Eds.), Impulsivity and aggression (pp. 185-200). New York: Wiley.

Foxx, R. M. (1982). Decreasing behavior of severely retarded and autistic persons. Champaign, IL: Research Press.

Foxx, R. M. (2003). The treatment of dangerous behavior. Behavioral Interventions, 18, $1-12$.

Gardner, A. R, \& Gardner, A. J. (1975). Self-mutilation, obsessionality, and narcissism. British Journal of Psychiatry, 127, 127-132.

GeoCities. (n.d.). Alternatives to self-injury. Retrieved November 12, 2003, from http:// www.geocities.com/HotSprings/6446/alternatives.html

Graff, H., \& Mallin, R. (1967). The syndrome of the wrist cutter. American Journal of Psychiatry, $124,36-42$.

Gratz, K. L. (2001). Measurement of deliberate self-harm: Preliminary data on the Deliberate Self-Harm Inventory. Journal of Psychopathology and Behavioral Assessment, 23, 253-263.

Haines, J., \& Williams, C. L. (1997). Coping and problem solving of self-mutilators. Journal of Clinical Psychology, 53, 177-186.

Herpertz, S. (1995). Self-injurious behavior. Acta Psychiatrica Scandinavica, 91, 57-68.

Himber, J. (1994). Blood rituals: Self-cutting in female psychiatric inpatients. Psychotherapy, 31, 620-631.

Kravitz, H., Rosenthal, V., Teplitz, A., Murphy, J. B., \& Lesser, C. E. (1960). A study of headbanging in infants and children. Journal of Diseases and Nervous System, 21, 203-208.

Levenkron, S. (1998). Cutting: Understanding and overcoming self-mutilation. New York: Norton. Mosaic Minds. (n.d.). Staying safe: Alternatives to self-injury. Retrieved November 12, 2003, from http://www.mosaicminds.org/safe-asi-new.shtml

Pattison, E., \& Kahan, J. (1983). The deliberate self-harm syndrome. British Journal of Medical Psychology, 140, 867-872.

Pipher, M. (1994). Reviving Ophelia: Saving the selves of adolescent girls. New York: Ballantine Books. 
Psyke.org. (n.d.). Self-injury information and support: Coping. Retrieved August 22, 2004, from http://psyke.org/coping/

Ross, R. R, \& McKay, H. B. (1979). Self-mutilation. Lexington, MA: Lexington Books.

Ross, S., \& Heath, N. (2002). A study of the frequency of self-mutilation in a community sample of adolescents. Journal of Youth and Adolescence, 31, 67-77.

Simeon, D., \& Favazza, A. R (2001). Self-injurious behaviors: Phenomenology and assessment. In D. Simeon \& E. Hollander (Eds.), Self-injurious behaviors: Assessment and treatment (pp. 1-28). Washington, DC: American Psychological Association.

Strong, M. (1998). A bright red scream: Self-mutilation and the language of pain. New York: Viking. Tantam, D., \& Whittaker, J. (1992). Personality disorder and self-wounding. British Journal of Psychiatry, 161, 451-464.

Turp, M. (1999). Encountering self-harm in psychotherapy and counseling practice. British Journal of Psychotherapy, 15, 306-321.

van der Kolk, B. A., Perry, J. C., \& Herman, J. L. (1991). Childhood origins of self-destructive behavior. American Journal of Psychiatry, 148, 1665-1671.

White Kress, V. E. (2003). Self-injurious behaviors: Assessment and diagnosis. Journal of Counseling of Development, 81, 490-496.

White, V. E., McCormick, L. J., \& Kelly, B. L. (2003). Counseling clients who self-injure: Ethical considerations. Counseling and Values, 47, 220-229.

Winchel, R. M., \& Stanley, M. (1991). Self-injurious behavior: A review of the behavior and biology of self-mutilation. American Journal of Psychiatry, 148, 306-317.

Yaryura-Tobias, J. A., Neziroglu, F. A., \& Kaplan, S. (1995). Self-mutilation, anorexia, and dysmenorrhea in obsessive-compulsive disorder. International Journal of Eating Disorders, 17, 33-38.

Zila, L. M., \& Kiselica, M. S. (2001). Understanding and counseling self-mutilation in female adolescents and young adults. Journal of Counseling or Development, 79, 46-52. 
Copyright of Journal of College Counseling is the property of American Counseling Association. The copyright in an individual article may be maintained by the author in certain cases. Content may not be copied or emailed to multiple sites or posted to a listserv without the copyright holder's express written permission. However, users may print, download, or email articles for individual use. 